\title{
1 \\ The German-language tradition of ethnography in Australia
}

\author{
Nicolas Peterson and Anna Kenny ${ }^{\top}$
}

Native title and statutory land claims under the Aboriginal Land Rights (Northern Territory) Act 1976 (Cth) and the Native Title Act 1993 (Cth) have been central to creating a renewed interest in early ethnographic accounts of Aboriginal life at a time when most current academic research into Aboriginal issues is focused on contemporary social problems, health matters and development. This is because to prove the existence of native title, Aboriginal claimants have to define the rights and interests in land that existed at sovereignty, identify the group that held these rights at that time, demonstrate a continued connection between these original rights holders, the contemporary claimants and their land and show how the rights and interests in the land are being exercised today. This has led anthropologists preparing claims to turn to the earliest ethnographic sources across the continent to establish what the original situation was likely to have been in a region and to demonstrate continuity of connection.

The Francophone emphasis in Australian and British education that lasted well into the middle of the twentieth century has meant that even other European languages such as Spanish and German are not widely known.

\footnotetext{
1 We would like to acknowledge the very useful comments from one of the anonymous referees on a draft of this chapter.
} 
Thus, without translations, there has been very limited incorporation of ethnography in German into Australian anthropological scholarship until recently, when translations have started to become available. Yet even so, this body of ethnography is not well known.

The purpose of this volume is to draw attention to this ethnographic corpus and to highlight interesting aspects of it to attract people to look into it further. While this volume provides a guide to the history of German-language approaches to ethnography and theorising, it is not an academic history of this field nor is there unanimity of views about that history. The approaches to the work of the various people discussed are eclectic, ranging from straight historical to others who choose to locate their account in terms of the relevance of old material to the present context. Further, most of the ethnographers in the earlier part of Australia's contact history whose work is discussed here were not professional anthropologists but often missionaries or interested people of means.

A specifically German anthropological orientation emerged in late Enlightenment and early Romanticist thought, which André Gingrich (Chapter 2, this volume) suggests embodied a tension in understanding other human lives between a universalism derived from Immanuel Kant and the Johann and Georg Forster father and son collaboration, on the one hand, and a relativism derived from Johann Gottfried Herder and the von Humboldt brothers, Alexander and Wilhelm, on the other. The relativistic approach emphasised the significance of language for understanding other people's particularity, because language was seen as the embodiment of a people's Geist. As early as 1828, Goethe observed that a number of Herderian ideas had become absorbed into the mainstream of philosophical and, ultimately, anthropological thought (Marchand 1982: 20). In his memoirs, Dichtung und Wahrheit, Goethe (1998: 430) commented that one of the most significant occurrences in his life was his acquaintance with Herder, whom he had met by chance in the Gasthof zum Geist. A key focus of this German tradition was 'Ethnologie', which was a concern with the relationship between cultural groups in historical and geographical perspective but was broader than the later American usage of ethnology because it included a concern with material culture, as well as mythology, ritual and language.

The emphasis on cultural multiplicity reflected in language was taken up by Adolf Bastian and his anthropological circle in Germany-in particular, by Franz Boas, who exported it to North America-and became their 
main methodological tool for empirical investigations. The meticulous and diligent study and collection of language data, especially through original texts of myths and songs, were central particularly because language was seen as the marker of humanity. It is not surprising, therefore, that linguists working in Australia are the ones who have made the most use of the material in German. As far as native title goes, the early work of the Lutheran missionaries in South and Central Australia (e.g. see McCaul, Chapter 3; Lucas and Fergie, Chapter 4, both this volume) has been most important, but later work has also been significant in demonstrating continuity of practices (see Redmond, Chapter 16, this volume). This German ethnography has also become of interest in contemporary Australia in the context of intellectual repatriation of cultural materials to Aboriginal communities concerned with cultural revitalisation of languages, traditional art forms and social practices.

However, it would be wrong to assume that just because missionaries paid attention to language, they automatically paid attention to culture. In most cases, the recording of mythical narratives and Aboriginal customs was a by-product of their linguistic work, which was focused on Bible translations. The major ethnographies by missionaries such as J. G. Reuther (1861-1914) and Carl Strehlow (1871-1922) were mainly the result of the guidance of mentors from the scientific world in urban centres in Germany (Völker 2001) and Australia. It is very unlikely, for example, that Carl Strehlow would have made his ethnographic investigations without the constant probing and support of his armchair anthropologist friend and mentor, Baron Moritz von Leonhardi (1856-1910) (Kenny 2013), who also corresponded with Reuther and Otto Siebert (1871-1957). Reuther and Siebert were correspondents as well of Alfred Howitt (1830-1908) in Melbourne.

Beyond native title, interest in German-language ethnography has come from outside social and cultural anthropology, with the growth of research into the rock art of the Kimberley region and material culture studies. Although the existence of this art has been known since the mid-1830s and there had been some documentation of it beginning with Ian Crawford (see 1968), it was the systematic work by Grahame Walsh, a self-funded researcher (Morwood 2002: 52), that has resulted in the documentation of nearly 1,000 sites on the Kimberley Plateau and has been principally responsible for the growth of interest. Because members of the 1938-39 Frobenius Institute Expedition had published major untranslated ethnographies on the Kimberley, Walsh was keen to 
gain access to them. His work stimulated the interest of local pastoralist Susan Bradley in the art, and influenced the Myer family of Melbourne to purchase two pastoral leases in the area to support his research. With Bradley's help, Walsh organised the translation and publication in 1997 of Andreas Lommel's Die Unambal, originally published in 1952, and in 2011 of Helmut Petri's Sterbende Welt in Nordwest Australien, originally published in 1954. The Association of Australian Decorative and Fine Arts Societies (AADFAS) funded both translations. ${ }^{2}$ More recently, this translation of German ethnography has received another boost under the influence of Kim Akerman, an anthropologist with a strong interest in Kimberley material culture, who has been instrumental in having Petri's 'Der Australische Medizinmann' (1952) translated and published by Hesperian Press in 2014, and, in 2015, a collection of translations of articles by German ethnographers on northern Western Australia (Akerman 2015).

Australian ethnography produced by German speakers can be divided into three broad phases. The initial work was almost entirely by German-speaking missionaries of Lutheran and Moravian background, who gathered their material from the 1830s until the early twentieth century. A second phase overlapping with this first period runs from the beginning of the twentieth century until the 1930s, during which time a very small number of researchers, who may be broadly characterised as 'men of science', were active. A third phase runs from the late 1930s to the present and is characterised by the work of professionally trained anthropologists writing mainly in German, but more recently in English. Taken together, this work has three principal regional focuses: northeastern South Australia among the Diyari (Dieri) ${ }^{3}$ and their neighbours; Central Australia among the Aranda; and the Kimberley region of Western Australia. There is important work from elsewhere such as Cape York and southern South Australia, too, as emerges clearly from the chapters in this book by Corinna Erckenbrecht (Chapter 6) and Kim McCaul.

2 Neither the publications that have been translated with AADFA support nor the various websites provide any detailed information as to which of the many Australian branches supported the translation.

3 Diyari is a modern rendering of the people's name. The common spelling in the past was Dieri, which is still used by the people themselves today. 


\section{First encounters: Missionary anthropology}

The prejudice of anthropologists towards missionaries and their missionising is well known but that has not extended to their ethnographic work in anything like the same degree. It is safe to generalise that most missionaries arrived in remote regions well before anthropologists and, until anthropology became a fieldwork-based discipline, the founding fathers of anthropology worldwide relied heavily on the reports of missionaries in particular, and, to a lesser extent, on travellers and explorers for their information.

Kenelm Burridge, in his neglected book Encountering Aborigines (1973: 5), makes a persuasive case that anthropology has a European signature. Indeed, he asks whether there would have been ethnographic studies of Aboriginal social and cultural life if Australia had been colonised from outside Europe. Colonisation, he argues, is only one aspect of that European signature. Another is anthropology's Christian inflexion that combines objective accounts of things as they are with engagement. While Christianity keeps these in a dialectical engagement, anthropology placed them in a 'taut and unsynthesised opposition' (Burridge 1973: 23). Both also share, in their different ways, a concern with how things might be. Thus, Burridge argues that a Christian ambience has contributed to an awareness of otherness and a desire to incorporate it. He also points out that missionary activity and anthropological monographs were:

continually infusing the European homeland with experiences of otherness ... It has been the collective and accumulated experience of the missionary tradition, in short, which has prepared the European mind to accept rather than reject the strange or new experiences, and then come to terms with it. (Burridge 1973: 17)

Missionaries, particularly German missionaries, were substantial contributors to early accounts of 'otherness' here in Australia. One clear reason for this was their accomplishment as linguists and the emphasis their training placed on learning local languages. It was surely Clamor Schürmann's (1815-93) command of the Barngarla language of the Eyre Peninsula in South Australia that led to him being the first person to report matrimoieties in 1846 , and it was only command of local languages that could have resulted in the detail in the work of A. H. Kempe (1844-1928), L. G. Schulze (1851-1924), Reuther, Siebert and Carl Strehlow. The concern to learn local languages is testament to their 
education, especially those educated at the Neuendettelsau seminary, as is the marvellous photograph of Reuther in his study in remotest north-eastern South Australia in the 1890s (see Plate 4.3). Acquisition of the local languages required intensive work with Aboriginal people and led to further intensive work on the translation of hymns and sections of the Bible. While the Protestant theologian Gustav Warneck urged ethnography as a precondition of successful proselytisation, for some missionaries it seems the initial work on the language led to an interest in Aboriginal culture itself, way beyond what was required for their practical purposes. This is most clearly the case in respect of Otto Siebert at Killalpaninna (Bethesda Mission) and Carl Strehlow at Hermannsburg Mission-both of whom were criticised for spending too much time on ethnographic inquiry.

Their ethnographic zeal was also combined with a very active involvement in the collection of material culture for sale to support the mission. On the other hand, J. G. Reuther, who was also at Killalpaninna, initially claimed in 1892 that his only purpose in acquiring knowledge of the Diyari language and life was to 'find the points of contact with the Christian faith, and thereby to destroy their pagan concepts' (quoted in Scherer 1979: 14). Nevertheless, his ethnographic corpus of material eventually filled 13 volumes, with considerable attention paid to placenames and their associated mythology, and seems to clearly indicate a change of heart. Rod Lucas and Deane Fergie explore in fascinating detail Reuther's realisation of the importance of place to the Diyari and how he engaged his co-worker, Harry Hillier, to prepare a map to show some of the 2,449 placenames he recorded. He also commissioned an extensive collection of toas, the somewhat mysterious so-called direction signs-objects that have been the focus of considerable research and debate (e.g. see Morphy 1977; Jones and Sutton 1986). Indeed, Reuther's interest in material cultureso dramatically displayed in the photograph of the central corridor of his house, with its more than 1,000 artefacts (see Plate 4.4) — when added to the reports of Siebert and Hillier organising the sale of artefacts from the community at Killalpaninna to museums, clearly underlines the intensity of the artefact industry, especially in light of the fact that there were only 200 adults at Killalpaninna and most, if not all, of the wooden items would have been made by the 50 or so adult men. This focus on artefacts was driven not just by the need to generate income for the mission, but also, more generally, by the place of museums and material culture in German anthropology of the time (see Gingrich, Chapter 2, this volume). 


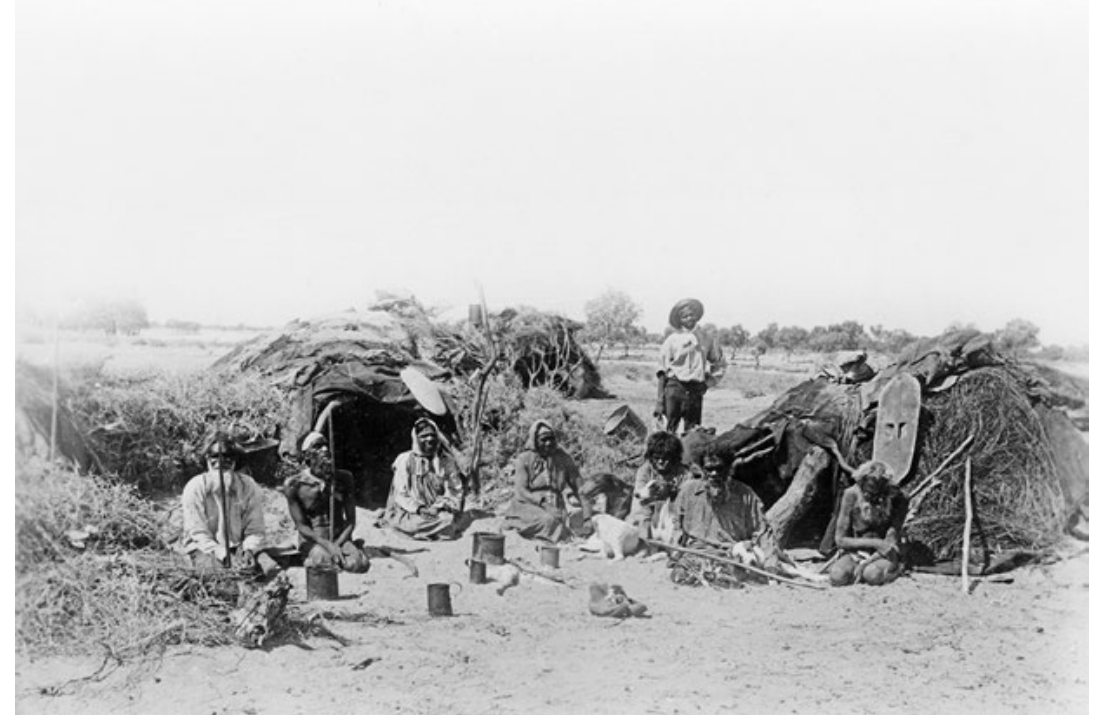

Plate 1.1 A Dieri family at a camp just outside of Killalpaninna Mission.

Source: SRC 06182, Strehlow Research Centre, Alice Springs.

Luise Hercus (Chapter 5) explores linguistic aspects of Reuther's 4,000-word Diyari dictionary, his comparative wordlists of seven other languages of the Lake Eyre region with 1,744 single gloss entries for Arabana, Yawarrawarrka, Wangkangurru, Kuyani, Ngamini, Thirrari and Yandruwandha and the related volume with the 2,449 placenames to reflect on his methodology and the enormous amount of detailed information his work contains. She shows the richness of his ethno-linguistic oeuvre and what can be learnt from it, but also demonstrates the problems these types of raw data pose. She uses particular words as examples to show how these problems might be overcome with the help of comparative linguistic materials and comparison with later ethnographic records, some of which she collected in the 1960s and 1970s from Aboriginal people from the Lake Eyre Basin.

In his consideration of the intellectual influences on these Lutheran missionaries, André Gingrich warns against drawing too strong a contrast between the social evolutionism of Baldwin Spencer and the British school, and the romantic humanism of the German researchers. Although Herder's views were important, they included a moderate evolutionism, reflecting his acceptance of universalism. The essential point was the acceptance that people such as the Aborigines had souls, even if they were seen as inferior, and, as a result, it was important to learn their language 
as a key to accessing their belief system and mythology. This emphasis on language learning, mythology and beliefs makes these early German missionary recorders' work invaluable in terms not only of general ethnography, but also linguistically, and marks it out from much of the work of the Anglophone ethnographers of the time. ${ }^{4}$

Although the Moravian missionaries first arrived in Australia in 1849, with their main efforts in Victoria, they extended their work to western Cape York in 1891, first by establishing Mapoon, then Weipa in 1898 and Aurukun in 1904. The training provided to these missionaries was quite different from that given to those with Lutheran backgrounds and was a great deal more practical, including not only gardening and farming, but also, interestingly, photography. Corinna Erckenbrecht has found an enormously rich archive in Herrnhut, Saxony, documenting the early years of these missions, which includes a fascinating visual record along with the many letters, journals and reports sent back to the mission headquarters. One particularly intriguing reference is to the early establishment of an orphanage at Mapoon in 1892, initially with three orphans brought by John Douglas from Thursday Island. The Cape York missionaries seem to have encountered greater difficulty in learning the languages of the region than the Lutherans in Central Australia, especially because of their number. Like the Lutherans, they, too, made collections of artefacts for sale to German museums. ${ }^{5}$

\section{Impact of the Aranda ethnography}

Although the ethnographic work by missionaries to the Aranda falls within this first phase, the key figure, Carl Strehlow, deserves separate treatment because of the role that Aranda ethnography has played in Australian anthropology, the size of his corpus, his engagement with Moritz von Leonhardi in Germany and his influence on his son, T. G. H. Strehlow (1908-78).

4 Of course, Malinowski emphasised the importance of fieldworkers learning the local language and Radcliffe-Brown, then foundation professor of anthropology at the University of Sydney, arranged funding for an American linguist of German background, Gehard Laves, to work in Australia towards a doctorate, which he never finished. Nonetheless, Laves's fieldnotes in the Australian Institute of Aboriginal and Torres Strait Islander Studies (AIATSIS) in Canberra have proved valuable to linguists and in native title claims.

5 An important secular collector was Amalie Dietrich, active in Queensland between 1863 and 1972, and working for a private museum in Hamburg (see Sumner 1993). 
If there is one thing that has long been known about German ethnography in Australia, it is the conflict between this Lutheran missionary to the Aranda at Hermannsburg, west of Alice Springs in Central Australia, and Sir Baldwin Spencer, professor of biology at the University of Melbourne and co-author with Frank Gillen of The Native Tribes of Central Australia (1899). The details of this conflict have been examined at length by a number of authors (e.g. see Strehlow 1947; Veit 2004; Strehlow 2004; Kenny 2013). The central issue was whether there was a concept of 'high $\operatorname{god}(s)$ ' (see Hiatt 1996) among the Aranda and more generally in Australia and the full significance of the term altjira, which the Lutherans used as the translation for 'God'. Spencer aligned himself with Edward Tylor and Sir James Frazer and a strong evolutionary perspective that saw Aranda ceremonies as magical and the precursor to religion. Carl Strehlow's report of high gods among the Aranda was at complete odds with this view, as was treating Aboriginal beliefs and practices as religious. In Spencer's view, Strehlow failed to realise that his report of high gods as Indigenous was quite wrong and that such beliefs were the result of Christian missionary activity. In this conflict, which was a key factor in marginalising Strehlow's work, the Australian anthropological fraternity clearly sided with Spencer until recently, as Walter Veit (2004: 108-9) notes, mainly because of their view that missionaries were 'prejudiced interlopers'. However, a number of scholars in the United Kingdom referred very favourably to Carl Strehlow's work. In 1933, A. M. Hocart (1933), for instance, pointed out that Strehlow's works were much stronger in their textual evidence than Spencer's and Gillen's. Hocart, however, belonged to a very different anthropological tradition than either Frazer or Alfred Radcliffe-Brown. Northcote Thomas (1905) also corresponded in German with Strehlow, raising questions over Spencer and Gillen's published accounts. ${ }^{6}$

Schulze and Kempe, the original missionaries who helped establish Hermannsburg Mission in 1877, $125 \mathrm{~km}$ west of Alice Springs, were not trained at the Neuendettelsau seminary in southern Germany, but were graduates of the Hermannsburg seminary in northern Germany, which was less academically oriented. Nevertheless, it was Kempe's work on the Aranda language that laid the foundation for Carl Strehlow's rapid competency in the local language when he arrived in 1894. As early as 1880 , they had produced a school primer and a book of Bible stories as

6 We are grateful to one of the anonymous reviewers for pointing out this evidence about the reception of Strehlow's work in the United Kingdom. 
well as hymns in Aranda. From Schulze's brief ethnographic output, it is clear that he was a sensitive observer recognising the ceremonies for what they were: religious celebrations.

Carl Strehlow was said to be preaching in Aranda within six months of his arrival at Hermannsburg and to be collecting material on linguistics and mythology at that time as well. However, he started writing his ethnographic work only in response to the inquiries from Leonhardi after the turn of the twentieth century, completing it in a five-year period (1905-10). The known manuscripts of Carl Strehlow's published work were destroyed in World War II during the bombing of the Ethnological Museum of Frankfurt. However, these were only duplicates provided to his editor. The original handwritten manuscripts survived because Strehlow had copied them and sent them in segments to Germany for comment and publication (Kenny 2013: 37). These manuscripts consist of three volumes, titled Sagen ('myths'/'legends'), Cultus ('cults') and Leben ('life'), and are now held at the Strehlow Research Centre in Alice Springs in Central Arrernte territory. Sagen contains the collection of myths, Cultus contains the songs that were sung during ceremonies and describes the choreography and paraphernalia of these rites and ceremonies and Leben describes aspects of social life. They were published in seven instalments as Die Aranda- und Loritja-Stämme in Zentral-Australien between 1907 and 1920 and are the richest and densest ethnographic writing on Western Aranda and Loritja cultures of Central Australia at the beginning of the twentieth century. His meticulous ethno-linguistic work also included a comparative dictionary of more than 7,600 Aranda and Loritja terms glossed in German, along with 1,200 Dieri (Diyari) words that remained unpublished at the time due to the death of his editor, and a comparative grammar of Aranda and Loritja. The comparative dictionary and grammar had the purpose 'to ascertain by comparison that Loritja and Aranda were two distinct languages, in structure and vocabulary" and to illustrate some theoretical points of the emerging Kulturkreislehre ('culture circle theory'; see below) school.

7 Letter from Moritz von Leonhardi to Carl Strehlow, 3 April 1909, held at the Strehlow Research Centre, Alice Springs. 


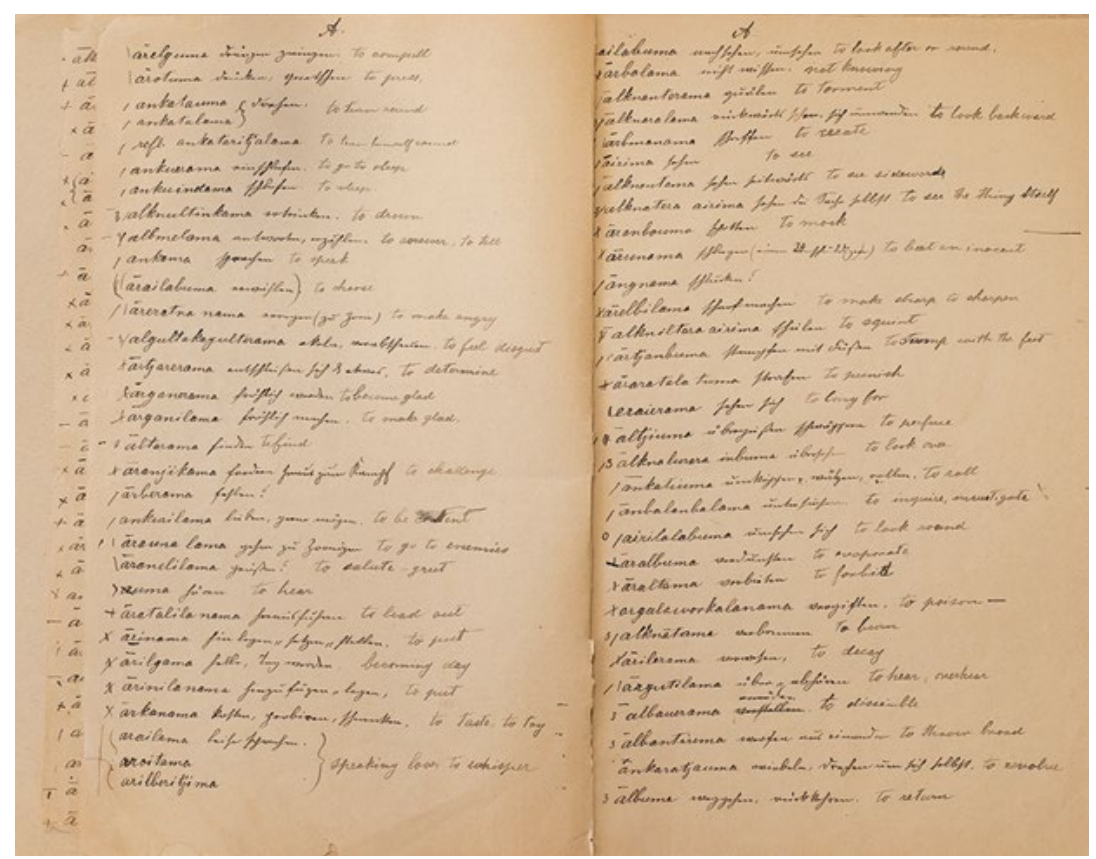

Plate 1.2 Kempe's Aranda to German wordlist with English translation by T. G. H. Strehlow, 1877-91.

Source: Image courtesy of Strehlow Research Centre, Alice Springs.

In her contribution, Anna Kenny (Chapter 7) concentrates on three key ethnographic topics discussed in the works of Kempe, Schulze and Strehlow senior that have direct relevance today: the altjira concept mentioned above, the subsection system and the links to the mother's country (place). It is a tribute to Schulze that he discovered the eight-class system, even if he struggled to get on top of it, leaving it to Carl Strehlow to do so. The significance of the mother's country is a major theme of most native title claims today and is central to ceremonial life. Although the concern with the eight-class system and links to the mother's country relate to social organisation, as well as genealogy to some degree, more detailed investigation of kinship and marriage were clearly avoided, as Gingrich emphasises — an avoidance that lasted until the 1970s among missionaries to the Aranda. ${ }^{8}$

8 Despite the continuing tradition of the Lutheran missionaries mastering Aranda, they had no grasp of the social and territorial organisation of the people at Hermannsburg until two of them took a course in anthropology at the University of Queensland in the mid-1970s, in which they learnt about the significance of patrilineal descent groups and ideology. 


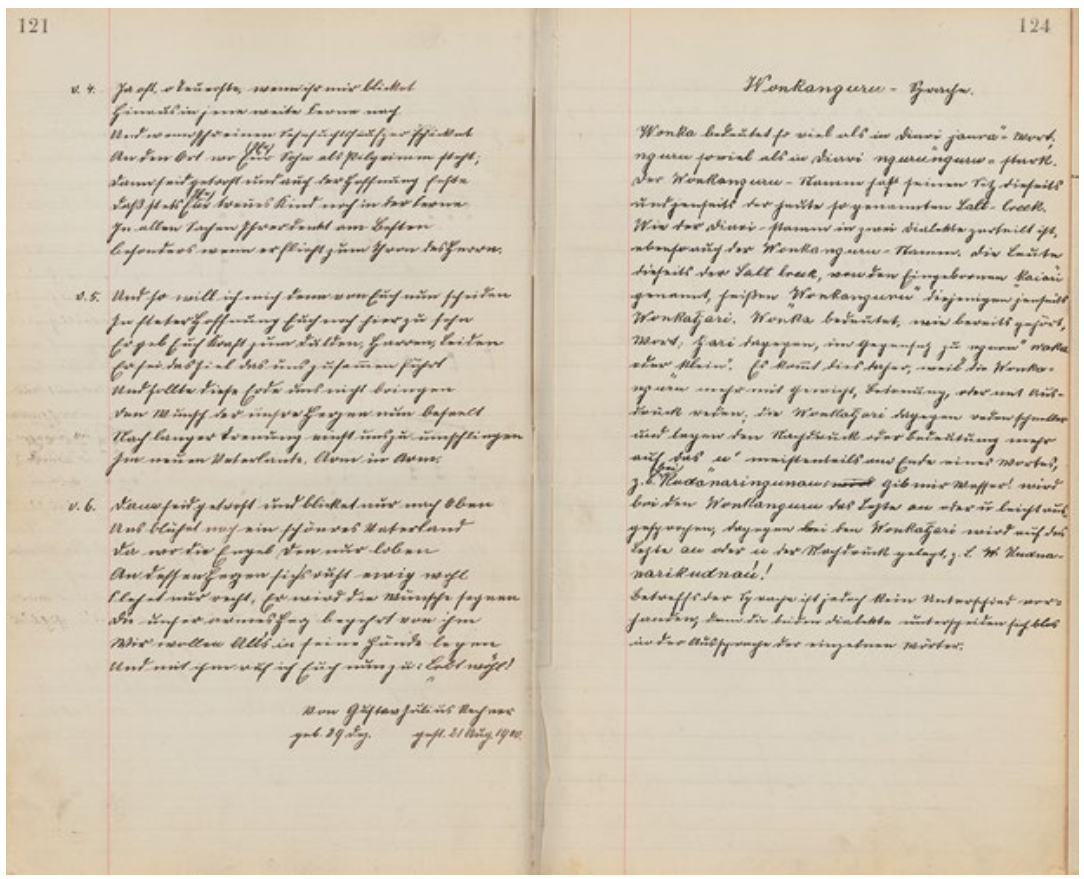

Plate 1.3 Pages of Reuther's manuscript of volume 5 containing data about eight languages of the Lake Eyre Basin, date range 1891-1904.

Source: South Australian Museum, Adelaide, AA-9-5, pp. 121, 124.

Because there is no published translation of Carl Strehlow's work, there is little awareness of its significance in the Anglophone world, although Kenny's (2013) book on Carl Strehlow describes his key findings to make them accessible to people outside a small cadre of regional specialists. ${ }^{9}$ At the time of the work's original publication, both Andrew Lang and N. W. Thomas in the Anglophone world recognised its importance, and Strehlow's work had considerable impact in Europe, where Marcel Mauss, Arnold van Gennep and others made good use of it (Kenny 2013: 101). However, besides the language problem, and Spencer's denigration of Strehlow's work, the outbreak of the war and the rise of Nazism resulted in any further interest in his ethnography dropping off.

Carl Strehlow's work was, however, a major influence on his son's anthropological research starting in the 1930s, and indeed provided the blueprint for his son's oeuvre. But, as John Morton (Chapter 8) argues,

9 The work has not been published in English as Aranda men are concerned about the amount of restricted information included in the seven volumes. 
there is clear evidence of a strongly oedipal relationship across successive generations in the Strehlow line, and, even though, as he says, T. G. H. Strehlow's 'anthropological journey is inseparable from his father's', T. G. H. never acknowledged his enormous debt to Carl. This despite drawing on every aspect of his father's work, from his extensive Aranda and Luritja dictionary to his extended genealogies and his translations of myths and songs. Indeed, T. G. H. was poor at acknowledging the works of others more generally and there are, according to Jason Gibson (Chapter 10), no references to either German or American anthropologists in his work or notes. It was only late in his career that he started looking towards North America, where his work might have found greater acceptance, and that he began to incorporate more theoretical thoughts on language into his papers as well as references (Kenny and Mitchell 2005).

Although T. G. H. Strehlow's work is well known because it is all in English, neither he nor his work was ever fully embraced by British social anthropology. Despite two years at the London School of Economics (LSE) that he had hoped would bring the recognition of a $\mathrm{PhD}$, on the basis of his published work, neither Raymond Firth, the head of anthropology there, nor A. P. Elkin in Sydney was really impressed with his anthropology (see Austin-Broos, Chapter 9, this volume). Both Diane Austin-Broos and Jason Gibson suggest that the reason for this was because T. G. H. Strehlow's interests were too particularistic and highly empirical, which, together with the focus on ritual, did not fit the prevailing social anthropological interests in kinship and social organisation. Nevertheless, Austin-Broos argues that, with access to his father's rich genealogical work, to which he made very substantial additions by linking kinship and marriage with totemic affiliations so assiduously marked for most people, T. G. H. has in fact mapped out the wider regional social system. This regional emphasis is shown as a ritual network and the fact that the genealogies have no ego reference point, but are named in relation to one or more apical ancestors, underlines this.

There was another, quite different aspect to Strehlow junior's regionalism that has been ignored, as Gibson documents. He worked much more widely in Central Australia than just with the Western, Eastern and Southern Aranda, spending considerable time with people to the north speaking Anmatyerr. Gibson emphasises just how keenly T. G. H. took up film and wire recording in the documenting of ceremonies. Interestingly, many of these recordings were made at religious festivals - very much in the tradition of Baldwin Spencer and Frank Gillen in 1896. This work on 
ceremonial life is yet another reason T. G. H. Strehlow's work, like that of his father, is not well known, since it is restricted mainly because of the secret-sacred content.

In his chapter, Morton examines the currents that link T. G. H. Strehlow's work with that of Freud, mediated by Géza Róheim (1891-1953). Although Hungarian, Róheim wrote in both German and English and conducted fieldwork for nine months with the Aranda and Pitjantjatjara in 1929. Morton outlines the influence of Róheim and his psychoanalytic approach on T. G. H., who commented that he felt 'the Freudian school has some excellent suggestions to offer in regard to the elucidation of aboriginal sacred myths and songs' (1971: xvi-xvii). But T. G. H.'s concern for 'absolute accuracy' in whatever he documented meant that he found Róheim's 'generally reckless and uneconomical approach to writing', as Morton puts it, problematic. Regardless of this, given the lack of credibility that psychoanalysis had among social anthropologists, it became yet another reason to add to the concern with ritual and his difficult personality for T. G. H.'s work not entering the mainstream of Australian anthropological scholarship in his lifetime. His time at the LSE had little impact on his orientation, and it is clear from both his writing and the fact that the Froebenius Institute approached him to join their 1938-39 expedition to Australia that his anthropological approach was still seen as being in tune with German orientations to anthropology.

\section{Widening the interest}

In terms of the chronology of work by German ethnographers in Australia, we need to go back to 1896 when the first of the published nonmissionary investigators arrived, making them more or less contemporary with Baldwin Spencer. This was Erhard Eylmann (1860-1926), a man of private means with a medical and natural science background. His book Die Eingeborenen der Kolonie Südaustralien (The Natives of the Colony of South Australia; 1908) has not been translated into English and for this reason alone is not well known. In her examination of Eylmann's book, Francesca Merlan (Chapter 11) draws attention to the rather unusual nature of his writing, which combines a scientific reporting style with personal writing that gives a feeling for the subjective experience of fieldwork, and a touch of a modern sensibility to his writing. 
At much the same time (1904-07), Hermann Klaatsch (1863-1916) was in Australia. He, too, had a medical background, with a particular interest in physical anthropology and the theory of his friend Otto Schoetensack that the human race had originated in Australia—an idea he soon realised was unlikely. Gingrich comments that there was a growth of interest in physical anthropology at this period. Klaatsch's life and work have been given extended treatment by Corinna Erckenbrecht (2010). Although he was interested in and made a large collection of material culture and wrote about aspects of social life, being critical of Spencer's ideas on totemism (see Erckenbrecht 2010: 194), Klaatsch's only book-length work in English was an analysis of the W. E. Roth collection of skulls in the Australian Museum (see Klaatsch 1907) and he died before publishing a major work on Australia.

The first scholar with a German background to publish an encyclopedic text on Aboriginal ethnography was Herbert Basedow (1881-1933), author of The Australian Aboriginal, published in English in 1925. Apart from three years of primary education in Germany, Basedow was educated in Adelaide, going on to do science at the University of Adelaide. When he was 26, he travelled to Germany for postgraduate work, studying science and medicine under Hermann Klaatsch. For one of his two PhDs, Basedow wrote on Aboriginal crania in relation to the ideas that Aboriginal people were 'black Caucasians'. In Basedow's complex career following his return to Australia, David Kaus (Chapter 12) shows that his anthropological work was always secondary to his prospecting or medical employment. There was considerable scepticism about his medical training, because of the rapidity with which it was acquired, and this scepticism seems to have spilt over to his ethnographic work, which was not held in high regard by his contemporaries, all the more so because his book does not reference other people's work even where he has drawn on it.

The first person to work with an explicitly Kulturkreislehre or diffusionist approach in Australia was Father Ernest Worms (1891-1963) of the Pallottine mission, who arrived in the Kimberley in 1930. Although a missionary, his concern with anthropological research in Aboriginal languages and religion was of a professional standard, as William McGregor (Chapter 13) shows, so he can be seen as a 'man of science'. Almost immediately after arrival, he began research on the Indigenous languages of the region, and was joined by his former teacher Hermann Nekes (1875-1948) in 1935. Together, while effectively 'interned' in Melbourne during the war, they prepared a magnum opus on Australian 
languages, which was distributed on microfilm in 1953 but not published until 2006. Worms was also interested in Aboriginal religion but had little involvement in either sociolinguistics or social anthropology. He was concerned with the historical sequence of influences from the desert on Kimberley religion, which was eventually published as Australische Eingeborenen-Religionen in 1968, but not translated until 1986. Following Virchow, Worms saw the role of missionaries as being to collect information, leaving the theorising to the metropole. Regina Ganter (Chapter 14) reports that his strongly anti-evolutionist position led him to dismiss the work of Frazer, Tylor, Spencer and Morgan as 'premodern ethnology', preferring the new ethnology of Ratzel, Graebner, Frobenius and Schmidt because it 'harmonised with Catholic thought'. Indeed, it was through Worms's work that Schmidt's work on Australian languages and their sequencing was most influential. Ganter reports that 'in the early 1950s, one of Elkin's students ... produced a scathing critique of Catholic mission policy', so that, from then on, Worms no longer published in Oceania (which was edited by Elkin), but only in Anthropos.

Despite the rift with Elkin, W. E. H. Stanner (1905-81) invited Worms to present at the inaugural conference for the Australian Institute of Aboriginal and Torres Strait Islander Studies (AIATSIS) in 1961.

Indirectly, these Kulturkreislehre ideas influenced Norman Tindale (1976) and D. S. Davidson (1928), both of whom were interested in the spatial distribution of material culture and patterns of diffusion in Australia.

\section{Academic researchers}

The beginning of this phase is clearly marked by the Frobenius Institute Expedition to north-west Australia in 1938-39, with its two male anthropologists, Andreas Lommel (1912-2005) and Helmut Petri (1907-86), both of whom published book-length accounts of their work. Because Lommel's and Petri's books were not translated into English until 1997 and 2011, respectively, the impact of their work in Australia has been limited and is known largely through a few chapters in edited volumes and journal articles that were of interest mainly to regional specialists. However, Erich Kolig (Chapter 15) was very much an exception to this ignorance as a native German speaker from Austria who received his anthropological education at the University of Vienna. He was not only familiar with these works but also knew Helmut Petri and his wife, 
Gisela Petri-Odermann. Kolig reflects on his anthropological education to ask about the nature of this German anthropological tradition and the diverse influences on his approach. Although this includes Durkheim and Weber, the majority of people who have influenced his work are quite different from those influencing people in the social anthropological tradition until the recent phenomenological turn, and the nature of his own publications could never be mistaken for those of an Anglophone social anthropologist. Kolig came to the Kimberley region of Western Australia in 1970 as a postdoctoral researcher with full knowledge of Lommel's and Petri's works from the time of the Frobenius Expedition in 1938. Each wrote a book that was framed by a pessimistic historical perspective on the future, a framing influenced by Frobenius's ideas on cultural morphology and the analogy of cultures having 'life cycles'. Their historical orientation, even if negative, contrasted strongly in Kolig's eyes with the backward-looking and reconstructive bias of much of the work of Australian anthropologists going on when he arrived. Kolig's own work relates directly to Petri's concern with travelling cults and brought a strong interest in cultural change, which he saw in much more positive terms of resilience and cultural revivalism. Petri, too, became more positive, Kolig believes, as a result of his postwar research in Australia.

Silke Beinssen-Hess (1991) provides a comprehensive account of the background to Frobenius's interest in Australia and the organisation of the expedition, comprising originally Helmut Petri and Gisela PetriOdermann and then joined by Lommel as the third anthropologist. There were also two women painters for the recording of rock art, and later they were joined by Patrick Pentony, who worked on dreams and ended up as professor of psychology at The Australian National University. BeinssenHess provides a comparative account of the work of Petri and Lommel. While there is no doubt that Petri was the better scholar, Lommel was more widely known in Europe because of writings on Aboriginal art in German and extensively in English (e.g. see Lommel and Lommel 1959, and its translation), which have been strongly criticised by at least one Australian scholar (Beinssen-Hess 1991: 148). Beinssen-Hess also briefly mentions another member of the Frobenius research group on Australia, F. J. Micha, who had several publications in English (see 1959, 1970) and one major one in German (1958).

Lommel's work on the jurnba song cycle was the jumping off point for Anthony Redmond (Chapter 16) when he began his PhD research in the Kimberley in 1994. Redmond worked with some of Lommel's informants 
and collected further song texts from them and others, but also gained insights into how the Europeans of the Frobenius Expedition in 1938 were perceived and received by the Aboriginal people of Munja. He shows how they, as well as events occurring in the war years, left records of their social impact in their various song cycles.

Of the researchers working in an academic mode, the most problematic is Carl von Brandenstein (1909-2005), who started academic life as a Hurrinan-language expert at the Berlin Ethnological Museum. After internment in Australia during the war, he became involved with the Australian Institute of Aboriginal Studies early on, carrying out language surveys in Western Australia. His linguistic career can be divided into two phases: the earlier period in which he carried out extensive fieldwork recording and the latter period when his work became increasingly speculative. This speculation included his dubious views on Portuguese influence on the language of the Kimberley region, fitting with diffusionist thinking, but more significantly on the attempts at linking the classification of human temperaments and somatic types with the section and subsection systems. This work is highly controversial and made all the more problematic by his book Names and Substance of the Australian Subsection System, which was published by Chicago University Press in 1982. As Patrick McConvell points out, '[m] uch of his linguistic evidence is coincidence, dressed up as historical connection' (quoted in Thieberger, Chapter 17, this volume). No doubt, as Nick Thieberger suggests, von Brandenstein's lasting contribution will be the extensive field recordings he made of languages, many of which are no longer in daily use.

It is no accident that both Kolig and von Brandenstein received support and encouragement from Ronald Berndt (1916-90), the foundation professor of anthropology in Western Australia. Ronald Berndt was born in Adelaide to German-speaking parents but received his anthropological education at the University of Sydney and the LSE, and so was firmly in the social anthropological tradition. He wrote only in English. However, his own interests and sensibilities seem to be at odds with his training and his focus was on ritual, religion, mythology, art and collecting extensive texts with interlinear translations. Nicolas Peterson (Chapter 18) argues that this gives a Germanic inflexion to his work-the exact sources of which are a little unclear, but which he believes are related to Berndt's pride in his German background and the experiences of working in the South Australian Museum early in his life, in the context of a general empiricism that pervaded anthropology in Adelaide, influenced as it was 
by the natural and medical scientists who were the supporters of the discipline. In his concern for ethnography over anthropology, Berndt also had a soulmate in T. G. H. Strehlow, with whom he was good friends and who was one of his few supporters right up to Strehlow's death.

If Ronald Berndt marked the end of one era, educational and political currents in Europe have opened a new one, bringing a new wave of anthropologists with German backgrounds to Australia since the late 1980s. This has been in the form of a steady stream of German postgraduate students coming to work with Aboriginal people, some registered in German-speaking countries and others in Australia (e.g. see Musharbash 2008; Eickelkamp 2001; Heil 2003; Kenny 2013; Duelke 1998; Stotz 1993; Widlok 1992; Weichart 1997). Their interests in psychoanalysis, phenomenology and material culture are now partly tinged with the form of British social anthropological practice found in Australia today, which itself is more correctly seen as a mid-Atlantic mix.

\section{Conclusion}

There are several important ethnographers whose work has been left out of consideration here. Two people who worked in South Australia, Christian Gottlieb Teichelmann (1841) and Heinrich Meyer (1846) from the Dresden Mission Society have some profile as their work was written in English and reprinted early, in 1879 (see Woods 1879), but there are others whose work was quite unknown until recently. Foremost among these is William Blandowski (1822-78), who has now received considerable attention, thanks to the work of Harry Allen (see 2010; Darragh 2009). Although working in the 1850 s and 1860s, Blandowski was certainly a man of science, becoming the first director of what is now Museum Victoria. Allen has quite clearly understood Blandowski's intention to publish the first visual ethnography of Aboriginal life based on the assumption that it was similar across the continent. This assumption allowed him to draw, unacknowledged, on other people's imagery where he had gaps in what he was unable to document while on his expedition to the lower River Murray in 1859. What is so powerful in the images is, as Allen puts it, their 'highly engaging sense of Aboriginal sociality' (Allen 2010: 12); even if this was an artistic artifice, it captures so nicely the dense sociality of Aboriginal life, and, in that respect, many of the images could only have been drawn from the experience of being with Aboriginal 
people. The publication of the images he assembled for his book included the documentation of aspects of Aboriginal culture in the south of the continent that are elsewhere recorded only in words.

Another scholar whose work is not dealt with here because much of it is in English is Wolfgang Laade (1925-2013), professor of ethnomusicology at the University of Zurich from 1971 to 1990, who carried out field research in the Torres Strait. In 1971, he published the first of five to seven planned volumes devoted to the ethno-history and ethnography of Torres Strait oral traditions. He also made a very extensive collection of musical recordings (e.g. see Laade 1971, 1974).

Taking all the scholars who have been mentioned here together, it would clearly be an error to manufacture a coherent and self-conscious German tradition where it did not exist. However, it is also clear that whether the ethnographers were missionaries, scientists or academics, the interest in mythology, song and religion more generally, grounded in enormous respect for local languages, plus the skills and motivations to learn them, permeates the work of all the people reported here. It has, as a result, created a body of work that is quite distinctive and that has greatly enriched the ethnographic corpus on Australian Aboriginal life.

\section{References}

Akerman, K. (ed.). 2015. Cologne to the Kimberley: Studies of Aboriginal life in northwest Australia by five German scholars in the first half of the 20th century. Perth: Hesperian Press.

Allen, H. (ed.). 2010. William Blandowskis Illustrated Encyclopaedia of Aboriginal Life. Canberra: Aboriginal Studies Press.

Baessler, A. 1983 [1895]. A Picnic with Australian Aborigines at Wallaga Lake (NSW). Translated by D. Fraser. Canberra: Department of the Parliamentary Library.

Basedow, H. 1925. The Australian Aboriginal. Adelaide: F.W. Preece and Sons. 
Beinssen-Hesse, S. 1991. The study of Australian Aboriginal culture by German anthropologists of the Frobenius Institute. In From Berlin to the Burdekin: The German contribution to the development of Australian science, exploration and the arts, (eds) D. Walker and J. Tanpke, pp. 135-50. Sydney: UNSW Press.

Burridge, K. 1973. Encountering Aborigines: Anthropology and the Australian Aborigines. New York: Pergamon.

Campbell, I. (trans.). 1997. The Unambal: A tribe in northwest Australia by A. Lommel. Carnarvon Gorge, Qld: Takarakka Nowan Kas Publications.

Campbell, I. (trans.). 2011. The Dying World in Northwest Australia. Perth: Hesperian Press.

Crawford, I. 1968. The Art of the Wandjina: Aboriginal cave painting in Kimberley, Western Australia. Melbourne: Oxford University Press.

Crawford, I. (trans.). 2014. The Australian Medicine Man. Perth: Hesperian Press.

Darragh, T. 2009. William Blandowski: A frustrated life. Proceedings of the Royal Society of Victoria 121(1): 11-60.

Davidson, D. S. 1928. The Chronological Aspects of Certain Australian Social Institutions as Inferred from Geographical Distribution. Philadelphia: University of Philadelphia.

Duelke, B. 1998. Same but Different: Vom Umgang mit Vergangenheit. Traition und Geschichte im Alltak einer nordaustralilischen AboriginesKommune. Cologne: R. Koppe.

Eickelkamp, U. 2001. Pitjantjatjara women's art at Ernabella: Genesis and transformations. Unpublished $\mathrm{PhD}$ thesis. Heidelberg University, Heidelberg.

Erckenbrecht, C. 2010. Auf der Suche nach den Ursprungen: Die Australienreise des Anthropologen und Sammlers Hermann Klaatsch 1904-1907. Ethnologica NF Band 27.

Eylmann, E. 1908. Die Eingeborenen der Kolonie Südaustralien. Berlin: Dietrich Reimer (Ernst Vohsen). 
Goethe, J. 1998. Dichtung und Wahrheit. Stuttgart: Reclam.

Heil, D. 2003. Well-being and bodies in trouble: Situating health practices within Australian Aboriginal socialities. Unpublished PhD thesis. University of Sydney, Sydney.

Hiatt, L. 1996. Arguments about Aborigines: Australia and the evolution of social anthropology. Cambridge: Cambridge University Press.

Hocart, A. M. 1933. Arunta language: Strehlow v. Spencer and Gillen. Man 33(May): 92.

Jones, P. and Sutton, S. 1986. Aboriginal Sculptures of the Lake Eyre Region. Adelaide: South Australian Museum and Wakefield Press.

Kenny, A. 2013. The Aranda's Pepa: An introduction to Carl Strehlow's masterpiece Die Aranda- und Loritja-Stämme in Zentral-Australien (1907-1920). Canberra: ANU E Press.

Kenny, A. and Mitchell, S. (eds). 2005. Collaboration and language. Occasional Paper No. 4. Strehlow Research Centre, Alice Springs, NT.

Klaatsch, H. 1907. The skull of the Australian Aboriginal New South Wales. Pathological Laboratory Reports 1(3): 44-167. Lunacy Department, Sydney.

Laade, W. 1971. Oral Traditions and Written Documents on the History and Ethnography of the Northern Torres Strait Islands, Saibai-Dauan-Boigu. Volume 1: Aeh_Myths, legends, fairy tales. Wiesbaden, Germany: Franz Steiner.

Laade, W. 1974. Das Geisterkanu: Südseemythen und-märchen aus der Torres-Strasse. Kassel, Germany: Eric Roth.

Lally, J. 2008. The Australian Aboriginal collection and the Berlin Ethnological Museum. In The Makers and Making of Indigenous Australian Museum Collections, (eds) N. Peterson, L. Allen and L. Hamby, pp. 190-205. Melbourne: Melbourne University Press.

Langham, I. 1981. The Building of British Social Anthropology. Dordrecht: D. Reidel Publishing Company. doi.org/10.1007/978-94009-8464-6. 
Lommel, A. 1952. Die Unambal: Ein Stamm in Nordwest Australien. Hamburg. [English version 1997. The Unambal. Translated by I. Campbell. Carnarvon Gorge, Qld: Takarakka Nowan Kas Publications.]

Lommel, A. 1969. Fortschritt ins Nichts: die Modernisierung der Primitiven Australiens-Beschreibung und Definition eines psychischen Verfalls. Zurich: Atlantis.

Lommel, A. and Lommel, K. 1959. Die Kunst des funften Erdteils Australien. Munich: Staatliches Museum fur Volkerkunde.

Marchand, J. W. 1982. Herder: Precursor of Humboldt, Whorf, and modern language philosophy. In Johann Gottfried Herder: Innovator through the ages, (ed.) W. Koepke with S. B. Knoll, pp. 20-34. Bonn: Bouvier Verlag Herbert Grundmann.

Meyer, H. A. 1846. Manners and Customs of the Aborigines of the Encounter Bay Tribe. Adelaide: G. Dehane. [Reprinted in Woods, J. 1879. The Native Tribes of South Australia. Adelaide: E. S. Wigg \& Son.]

Micha, F. J. 1958. Der Handel der zentralaustralischen Eingeborenen. Annali Lateranensi [Vatican City] 22: 41-228.

Micha, F.J. 1959. DieTauschmittel an den Märkten der zentralaustralischen Eingeborenen. Anthropos 54(S): 377-400.

Micha, F. J. 1970. Trade and change in Aboriginal Australian cultures: Australian Aboriginal trade as an expression of close culture contact and as a mediator of cultural change. In Diprotodon to Detribalization, (eds) A. Pilling and R. Waterman, pp. 285-313. East Lansing: Michigan State University Press.

Morphy, H. 1977. Schematisation, meaning and communication in toas. In Form in Indigenous Art: Schematisation in the art of Aboriginal Australia and prehistory Europe, (ed.) P. Ucko, pp. 77-89. London: Duckworth Humanities Press.

Morwood, M. 2002. Visions from the Past: The archaeology of Australian Aboriginal art. Washington, DC: Smithsonian Press.

Musharbash, Y. 2008. Yuendumu Everyday: Contemporary life in remote Aboriginal Australia. Canberra: Aboriginal Studies Press. 
Nekes, H. and Worms, E. 2006. Australian Languages. Edited by W. McGregor. Berlin: Mouton de Gruyter.

Petri, H. 1952. Der Australische Medizinmann. Annali Lateranensi 16: 159-317. [English version 2014. The Australian Medicine Man. Translated by I. Campbell. Perth: Hesperian Press.]

Petri, H. 1954. Sterbende Welt in Nordwest Australien. Brunswick, Germany: Albert Limbach Publishers. [English version 2011. The Dying World in Northwest Australia. Translated by I. Campbell. Perth: Hesperian Press.]

Reim, H. 1962. Die Insektennahrung der Australischen Ureinwohner: Eine Studie zur Frühgeschichte Menschlicher Wirtschaft und Ernährung. Berlin: Akademie-Verlag.

Scherer, P. A. 1979. Donor of Aboriginal heritage. The Lutheran 13(12): $12-15$.

Semon, R. 1899. In the Australian Bush and on the Coast of the Coral Sea. London: Macmillan.

Spencer, W. B. and Gillen, F. J. 1899. The Native Tribes of Central Australia. London: Macmillan \& Co.

Stotz, G. 1993. Kurdungurlu got to drive Toyota: Differential colonizing process among the Warlpiri. Unpublished $\mathrm{PhD}$ thesis. Deakin University, Melbourne.

Strehlow, C. 1907-1920. Die Aranda- und Loritja-Stämme in ZentralAustralien. 7 vols. Frankfurt am Main: Joseph Baer \& Co.

Strehlow, J. 2004. Reappraising Carl Strehlow: Through the SpencerStrehlow debate. In Occasional Paper No. 3, (ed.) W. Veit, pp. 59-91. Strehlow Research Centre, Alice Springs, NT.

Strehlow, T. G. H. 1947. Aranda Traditions. Melbourne: Melbourne University Publishing.

Strehlow, T. G. H. 1971. Songs of Central Australia. Sydney: Angus \& Robertson.

Sumner, R. 1993. Amalie Dietrich and the Aborigines: Her contribution to Australian anthropology and ethnography. Australian Aboriginal Studies 2: 2-19. 
Teichelmann, C. 1841. Aborigines of South Australia: Illustrative and explanatory notes of the manners, customs, habits, and superstitions of the natives of South Australia. Adelaide.

Thomas, N. 1905. The religious ideas of the Arunta. Folklore 16(4): 428-33. doi.org/10.1080/0015587X.1905.9719976.

Tindale, N. 1976. Some ecological bases for Australian tribal boundaries. In Tribes and Boundaries in Australia, (ed.) N. Peterson, pp. 12-29. Canberra: Australian Institute of Aboriginal Studies.

Veit, W. 2004. The struggle for souls and science: Constructing the fifth continent, German missionaries and scientists in Australia. Occasional Paper No. 3, Strehlow Research Centre, Alice Springs, NT.

Völker, H. 2001. Missionare als Ethnologen. Moritz Freiherr von Leonhardi, australische Mission und europäische Wissenschaft. In Sammeln, Vernetzen, Auswerten. Missionare und ihr Beitrag zum Wandel europäischer Weltsicht, (ed.) R. Wendt, pp. 173-218. Tübingen, Germany: Gunter Narr Verlag.

von Brandenstein, C. G. 1982. Names and Substance of the Australian Subsection System. Chicago: Chicago University Press.

Walsh, G. 2000. Bradshaw Art of the Kimberley. Brisbane: Takarakka Nowan Kas Publications.

Weichart, G. 1997. Art in the centre: An overview of the production of art in Central Australia and its role in contemporary society. Unpublished thesis. University of Vienna, Austria.

Widlok, T. 1992. Practice, politics and ideology of the travelling business in Aboriginal religion. Oceania 63(2): 114-36. doi.org/10.1002/ j.1834-4461.1992.tb02408.x.

Woods, J. (ed.). 1879. The Native Tribes of South Australia. Adealide: G. S. Wigg \& Sons.

Worms, E. and Petri, H. 1968. Australische Eingeborenen-Religionen. In Eingeborenen-Religionen der Sudsee und Australiens, pp. 125329. Stuttgart: W. Kohlhammer. [English version 1986. Australian Aboriginal Religions. Sydney and Melbourne: Spectrum Publications.] 
This text is taken from German Ethnography in Australia, edited by Nicolas Peterson and Anna Kenny, published 2017 by ANU Press, The Australian National University, Canberra, Australia.

dx.doi.org/10.22459/GEA.09.2017.01 